
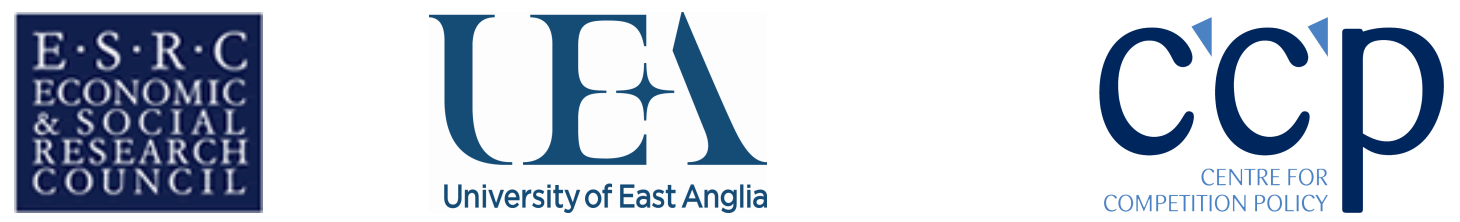

\title{
'Consumer Welfare' and Article 82EC: Practice and Rhetoric
}

\author{
by \\ Pinar Akman \\ ESRC Centre for Competition Policy and Norwich Law School, \\ University of East Anglia
}

\section{CCP Working Paper 08-25}

Forthcoming in (2009) 32 World Competition

\begin{abstract}
This paper questions whether the objective of Article 82EC is indeed enhancing 'consumer welfare' as suggested by the EC Commission when one examines the application of the provision thus far. It critically analyses the case law of the EC Commission and Courts to show that there is great dissonance between the practice and the policy declarations on the provision. When one considers the practice alongside the rhetoric, Article 82EC appears as a provision enforced without a clear standard of harm leading to doubts about the legitimacy of enforcement. The article suggests that without a properly defined standard applied in actual decisions by the EC Commission and upheld by the EC Courts, the modernisation of Article 82EC cannot succeed.
\end{abstract}

July 2008

JEL Classification Codes: K21, $\mathrm{P} 46$

Keywords: Article 82EC, consumer welfare, restriction of competition, abuse of a dominant position, enforcement

\section{Acknowledgements:}

The author would like to thank Morten Hviid, Michael Harker and Liza Lovdahl Gormsen for helpful comments. The usual disclaimer applies. The support of the Economic and Social Research Council is also gratefully acknowledged.

\section{Contact details:}

Pinar Akman, ESRC Centre for Competition Policy, University of East Anglia, Norwich, NR4 7TJ, UK

p.akman@uea.ac.uk 


\section{A. Introduction}

This paper questions whether the objective of Article 82EC prohibiting the abuse of a dominant position is enhancing 'consumer welfare' when one considers the application of the provision by the EC Commission and Courts alongside the policy declarations of the EC Commission. ${ }^{1}$ This question arises since as far as this author is able to detect, the term 'consumer welfare' has been used in merely two competition cases by the Court of First Instance (CFI) and has never been referred to by the European Court of Justice (ECJ). ${ }^{2}$ This is in sharp contrast with the policy declarations of the EC Commission in which 'consumer welfare' is repeatedly pronounced as a motto in reference to the ultimate objective of EC competition rules. According to the EC Commission DG Competition, the objective of Article 82EC is the 'protection of competition on the market as a means of enhancing consumer welfare and of ensuring an efficient allocation of resources'. ${ }^{3}$ Yet, as argued elsewhere, DG Competition has failed to articulate a clear test of harm based on consumer welfare which would have substantiated this claimed objective in its Discussion Paper on Article 82EC which is the most comprehensive document it produced on the application of the provision. ${ }^{4}$ This paper takes this argument further and seeks to show that the decisional practice of the EC Commission and Courts on Article 82EC similarly fail to substantiate and adhere to a clear test of harm based on consumer welfare. This is striking since as such Article 82EC appears to be a provision enforced without a clear standard of harm and this can raise doubts about the legitimacy of such

\footnotetext{
${ }^{1}$ Although there is no clear consensus on the definition of 'consumer welfare', this paper adopts the common understanding of 'consumer welfare' in economics: 'consumer welfare' is usually understood as 'consumer surplus' which is the aggregate measure of the surplus of all consumers. The surplus of a given consumer is the difference between her valuation of a good and the price she actually pays for it. 'Total welfare' is the sum of 'consumer welfare' and 'producer welfare'. 'Producer welfare' understood as 'producer surplus' refers to the sum of all profits made by producers in an industry; see M Motta Competition Policy: Theory and Practice (Cambridge University Press 2004) 18.

2 This is based on a Westlaw search of 'consumer welfare' as a 'term' in 'EU cases' (conducted on 21.07.2008). The two cases are Case T-168/01 GlaxoSmithKline Services Unlimited v EC Commission [2006] ECR II-2969 and Case T-201/04 Microsoft Corp v EC Commission [2007] 5 CMLR 11. In Microsoft the CFI merely refers to the Commission decision using the term; ibid [41]. 'Consumer welfare' is also referred to in the Opinion of Advocate General Jacobs in Case C-53/03 Synetairismos Farmakopoion Aitolias \& Akarnanias (Syfait) and Others v GlaxoSmithKline plc and GlaxoSmithKline AEVE [2005] ECR I-4609, [91], [92]. On this usage see text around n 80.

${ }^{3}$ EC Commission 'DG Competition Discussion Paper on the Application of Article 82 of the Treaty to Exclusionary Abuses' (Brussels, December 2005) available at http://ec.europa.eu/comm/ competition/antitrust/art82/discpaper2005.pdf [4], [54], [88].

4 P Akman 'Article 82 Reformed? The EC Discussion Paper on Exclusionary Abuses' [2006] (December) Journal of Business Law 816, 823-824, 828-829.
} 
enforcement. The discrepancy between practice and rhetoric provokes the question of whether 'consumer welfare' has merely become a slogan and in some cases legitimatisation of what is done in the name of 'consumers' or whether it is a genuine concern. The lack of consensus on what is meant by 'consumer welfare' and the fact that the EC Commission does not refer to 'consumer' in the sense of final-user which is the usual understanding of the term in consumer law casts further doubt on its genuineness. ${ }^{5}$

Article 82EC itself is not very helpful in resolving these questions: unlike Article 81EC which prohibits practices that 'have as their object or effect the prevention, restriction or distortion of competition' within the Common Market, Article 82EC merely states that 'any abuse by one or more undertakings of a dominant position ... shall be prohibited ... insofar as it may affect trade between Member States'. As such, Article 82EC does not express a requirement of prevention, restriction or distortion of competition and thus does not stipulate the precise objective(s) or a standard of harm for its application. However, since a dominant position itself is not prohibited and Article 82EC should be read in conjunction with Article 3(1)(g)EC which includes 'a system ensuring that competition in the internal market is not distorted' as one of the activities of the EC, it follows that there must be harm to something or someone for Article 82EC to be applicable. 'Abuse' must be understood as harm to something or someone and it can mean harm to competition, harm to competitors, harm to consumers or a combination of these to name a few. Currently, the standard remains ambiguous for both 'exploitative' and 'exclusionary' abuses although the emphasis in policy declarations appears to be on 'consumer welfare' ${ }^{6}$ This ambiguity leads to a

\footnotetext{
${ }^{5}$ See EC Commission Guidelines on the Application of Article 81(3) of the Treaty [2004] OJ C101/97, [84]; Discussion Paper ( $n$ 3) [55]. On the implications of understanding 'consumer' as 'customer' see $P$ Akman 'Consumer" versus "Customer": the Devil in the Detail' on file with the author.

${ }^{6}$ 'Exploitative' abuses can be defined as attempts by a dominant undertaking to exploit the opportunities provided by its market strength in order to harm customers directly. On the other hand, 'exclusionary' abuses are those practices, not based on normal business performance, which seek to harm the competitive position of the dominant undertaking's competitors or to exclude them from the market altogether; CE Mosso and S Ryan 'Article 82 - Abuse of a Dominant Position' in J Faull and A Nikpay (eds) The EC Law of Competition (Oxford University Press 1999) 146. Joliet had argued - based on the provision itself - that Article 82EC prohibited merely 'exploitative' abuses; R Joliet Monopolization and Abuse of Dominant Position (Martinus Nijhoff La Haye 1970) 250. Akman has more recently argued for the same view based on the travaux préparatoires of the EC Treaty; P Akman 'Searching for the LongLost Soul of Article 82EC' http://www.ccp.uea.ac.uk/publicfiles/workingpapers/CCP07-5.pdf, in particular text around n 16, n 105 and text after n 146.
} 
lack of ex ante business certainty which may result in undertakings acting overcautiously. This may in turn lead to businesses refraining from entering certain practices that may otherwise increase 'consumer welfare'.

Disputes concerning objectives are pervasive at both the decisional and the academic level. On the one hand, it has been remarked that to counteract criticism that EC competition law protects competitors rather than consumers would require, among other things, explicit proof of harm to consumers in all Article 82EC cases. ${ }^{7}$ It has been commented that although European competition law gradually assigns more weight to 'consumer welfare', its position does not yet resemble the same as in the US. ${ }^{8}$ Arguably, consumer welfare is neither the starting point nor the overriding interest in European competition analysis like it is in American antitrust law. The EC Commission puts emphasis on considerations other than 'consumer welfare', like the openness of the market with as many players as possible. ${ }^{9}$ It has similarly been noted that EC competition law does not require proof of harm to the consumer in order for either Article 81EC or Article 82EC to apply. ${ }^{10}$ The direct actual or potential effect of conduct on 'consumer welfare' is generally not considered. ${ }^{11}$ The primary concern of the competition authorities is the protection of the competitive process which is presumed to bring benefits to the consumer. ${ }^{12}$ On the other hand, it has been suggested that Article 82EC cannot make 'consumer harm' the ultimate test of anticompetitive conduct since Article 82EC protects the 'institution' of competition, namely the

\footnotetext{
${ }^{7}$ JT Lang Panel Discussion on Non-Pricing Abuses in CD Ehlermann and I Atanasiu (eds) What Is an Abuse of a Dominant Position? European Competition Law Annual 2003 (Hart Publishing Oxford 2006) 477. Lang argues that while this kind of proof could have been made in all Commission decisions based on Article 82EC, in practice this proof has not always been made explicitly; ibid.

${ }^{8}$ KJ Cseres Competition Law and Consumer Protection (Kluwer Law International The Hague 2005) 294. The difference is arguably that efficiencies do not yet form such an inherent part of the European assessment of consumer welfare and competition analysis as they do in the US; ibid.

${ }^{9}$ Cseres (n 8) 294. In the US, antitrust policy follows 'less of a pure consumer welfare' approach: it pursues an approach which takes short-term efficiency gains into account that generate long-term consumer benefits; ibid. The recognition of these efficiencies demonstrates the partial implementation of the total welfare approach. In contrast to the US approach, the European consumer welfare standard seems to be less concerned with long-term efficiency benefits for consumers; ibid 295. See also L Lovdahl Gormsen 'The Conflict between Economic Freedom and Consumer Welfare in the Modernisation of Article 82 EC' (2007) 3 (2) European Competition Journal 329, 339 et seq interpreting Article $82 \mathrm{EC}$ jurisprudence as aiming at protection of 'economic freedom' of rivals more than 'consumer welfare'.

${ }^{10}$ P Marsden and P Whelan '“Consumer Detriment" and Its Application in EC and UK Competition Law' (2006) 27 (10) European Competition Law Review 569, 576.

12 Marsden and Whelan (n 10) 584.
} 
competitive process itself, and this flows from the exercise of individual rights. ${ }^{13}$ This is grounded in the belief that the undistorted competitive process will generally tend to maximise wealth and consumer welfare. ${ }^{14}$ So far, the application of Article 82EC by the EC Commission and Courts appears to have been sufficiently broad in scope to embrace both ends of this spectrum making it very difficult to pinpoint their exact position regarding the objective(s) and the standard of harm of the provision.

Hence, this paper seeks to provide a non-exhaustive critical look at the case law of the EC Commission and Courts to see whether the decisional practice on Article 82EC indeed adopts a 'consumer welfare' standard as this is arguably the objective of this provision according to the policy declarations of the EC Commission. As such, it does not question whether 'consumer welfare' should be the standard of harm under Article 82EC. After examining the relevant decisional practice and policy declarations in Section B to show that there is significant dissonance between practice and rhetoric, it makes suggestions for the reconciliation of these in Section C. Section D concludes.

\section{B. Decisional Practice and Policy Declarations}

It is unfortunately not possible to identify a coherent and unified approach to the standard of harm under Article 82EC. The legal concept of 'abuse' is sufficiently abstract and capacious to allow multiple conceptions of its goals. ${ }^{15}$ Clashing views on the goals of the provision have caused uncertainty about the future of the law in this area impeding the capacity of European judges and administrators to apply the law consistently and effectively. ${ }^{16}$ As such, it is not easy to determine whether and how 'consumer welfare' plays a role in the enforcement of EC competition rules and specifically Article 82EC. Although

\footnotetext{
${ }^{13} \mathrm{~T}$ Eilmansberger 'How to Distinguish Good from Bad Competition under Article 82 EC: In Search of Clearer and More Coherent Standards for Anti-competitive Abuses' (2005) 42 Common Market Law Review 129, 133; H Schweitzer 'The History, Interpretation and Underlying Principles of Section 2 Sherman Act and Article 82 EC' in CD Ehlermann and M Marquis (eds) European Competition Annual 2007: A Reformed Approach to Article 82 EC (forthcoming 2008) available at http://www.iue.it/RSCAS/Research/Competition/2007(pdf)/ 200709-COMPed-Schweitzer.pdf 39.

${ }_{14}^{14}$ Eilmansberger (n 13) 133; Schweitzer (n 13) 39.

${ }^{15}$ DJ Gerber 'The Future of Article 82: Dissecting the Conflict' in CD Ehlermann and M Marquis (eds) European Competition Law Annual 2007: A Reformed Approach to Article 82 EC (forthcoming 2008) available at http://www.iue.it/RSCAS/Research/Competition/2007(pdf)/200709-COMPed-Gerber.pdf 1.

${ }^{16}$ Gerber (n 15) 1.
} 
this is a question of objectives and is thus fundamental if enforcement is to serve the appropriate objectives, it is surprisingly unsettled. It has indeed been pointed out that given that one of the fundamental objectives of EC competition law relates to the maximisation of 'consumer welfare', it is undeniably odd that neither 'consumer benefit' nor 'consumer detriment' has been given comprehensive treatment under either hard or soft EC competition law. $^{17}$

As regards the standard of harm, there seems to be two important aspects: first, whether the finding of 'abuse' has to be based on (actual or likely) effects of the conduct or whether such an assessment is not necessary and second, who or what is the subject on which abusive conduct must be observed. In other words, it must be determined whether it is harm to competitors, competition or consumers that cause conduct to be abusive. Both limbs of this issue are directly related to the current modernisation of the EC Commission's application of Article 82EC which arguably seeks to adopt an economics- and effects-based approach. ${ }^{18}$ Both limbs of the issue must be tackled to see whether 'consumer welfare' is the standard adopted in the decisional practice on Article 82EC.

\section{Are Effects Necessary for Conduct to be Abusive?}

The decisional practice is inconsistent on the necessity of (a showing of) anticompetitive effects under Article 82EC. ${ }^{19}$ On the one hand, several cases indicate that there must be a concrete assessment of a practice's effects on the market before a finding of material adverse effect can be made. ${ }^{20}$ On the

\footnotetext{
${ }_{17}^{17}$ Marsden and Whelan (n 10) 572.

${ }^{18}$ See e.g. N Kroes, European Commissioner for Competition Policy, 'The Commission's Review of Exclusionary Abuses of Dominant Position' Speech before the Korean Competition Forum organised on the occasion of the Fourth Annual Bilateral Meeting on 26/27 June 2006 in Seoul, 5 stating that ' $[\mathrm{t}$ the exercise of market power must be assessed essentially on the basis of its effects on the market'. According to the EAGCP Report commissioned by EC DG Competition, an effects-based approach focuses on the presence of anticompetitive effects that harm consumers and is based on the examination of each specific case, based on sound economics and grounded on facts. An economicsbased approach requires a careful examination of how competition works in each particular market in order to evaluate how specific company strategies affect 'consumer welfare'; Report by the Economic Advisory Group (EAGCP) for Competition Policy 'An Economic Approach to Article 82' (July, 2005) available at http://ec.europa.eu/comm/competition/publications/studies/eagcp_july_21_05.pdf 2.

${ }_{19} \mathrm{R}$ O'Donoghue and AJ Padilla The Law and Economics of Article 82 EC (Hart Publishing Oxford 2006) 217.

${ }_{20}$ See eg Case T-65/89 BPB Industries plc and British Gypsum Ltd v Commission [1993] ECR II-389, [65]-[66], upheld on appeal in Case C-310/93 P BPB Industries plc and British Gypsum Ltd v
} 
other hand, there are cases which find that an anticompetitive object or potential restrictive effects are sufficient to prove an abuse. ${ }^{21}$

For example, in British Gypsum, the dominant supplier of plasterboard was found to have abused its position by payments to builders' merchants who agreed to purchase plasterboard exclusively from British Gypsum Ltd. The CFI held that appraisal of the effects of exclusive purchasing commitments on the functioning of the market concerned depended on the characteristics of the market; it was thus necessary, in principle, to examine the effects of such commitments on the market in their specific context. ${ }^{22}$ In that case, the conclusion of exclusivity agreements in respect of a substantial proportion of purchases constituted an 'unacceptable obstacle to entry' to that market. ${ }^{23}$ Similarly in Van den Bergh both the EC Commission and the CFI have considered the effects of the freezer-exclusivity agreements the dominant icecream manufacturer entered into with retailers. The CFI held that the exclusivity clause had the effect of preventing the retailers from selling other brands of ice cream (even though there is demand for such brands) and of preventing competing manufacturers from gaining access to the relevant market. ${ }^{24}$ It is noteworthy that although in Van den Bergh mention is made of demand for the other non-dominant brands of ice-cream and thus effects on 'consumers' are considered, in British Gypsum the effects referred to are those on the 'market' which in this case relate to the possible foreclosure of the market to competitors. As such, there is no mention or assessment of

Commission [1995] ECR I-865; Case T-65/98 Van den Bergh Foods Ltd v Commission [2003] ECR II4563, upheld on appeal in Case C-552/03 P Unilever Bestfoods (Ireland) Ltd (formerly Van den Bergh Foods Ltd) v EC Commission [2006] 5 CMLR 27; Case T-83/91 Tetra Pak International SA v Commission [1994] ECR II-755, [151], upheld on appeal in Case C-333/94 P Tetra Pak International SA $v$ EC Commission [1996] ECR 1-5951. Similarly EC Commission decisions such as ECS/AKZO Commission Decision (Case IV/30.698) 85/609/EEC [1985] OJ L374/1, [86]; Deutsche Post AG Commission Decision (Case COMP/35.141) 2001/354/EC [2001] OJ L125/27, [37] et seq.

${ }^{21}$ See Case T-203/01 Manufacture Francaise des Pneumatiques Michelin v EC Commission [2003] ECR II-4071, [239]; Case T-219/99 British Airways plc v Commission [2003] ECR II-5917, [293], upheld on appeal in Case C-95/04 P British Airways plc v EC Commission [2007] ECR I-2331; Deutsche Telekom AG Commission Decision (Case COMP/C-1/37.451, 37.578, 37.579) 2003/707/EC [2003] OJ L263/9, [179]-[180].

${ }^{22}$ British Gypsum (CFI) (n 20) [66]. See also Case T-61/89 Dansk Pelsdyravlerforening $v$ EC Commission [1992] ECR II-1931, [99]; Case C-234/89 Delimitis v Henninger Braeu [1991] ECR I-935, [23], [28] et seq.

British Gypsum (CFI) (n 20) [68].

${ }^{24}$ Van den Bergh (CFI) (n 20) [160]. 
effects on 'consumers' which would be effects on the consumers of plasterboard, i.e. builders/building-owners.

In any event, there are also several cases where the effects of conduct were not deemed relevant at all such as Michelin II and Irish Sugar where the CFI held that for the purposes of applying Article 82EC, establishing anticompetitive object and anticompetitive effect are one and the same thing. ${ }^{25}$ If it is shown that the object pursued by the conduct of a dominant undertaking is to limit competition, that conduct will also be liable to have such an effect. ${ }^{26}$ According to the $\mathrm{CFI}$, the effect referred to in the case law on Article 82EC does not necessarily relate to the actual effect of the abusive conduct complained of; for the purposes of establishing an infringement of Article $82 \mathrm{EC}$, it is sufficient to show that the abusive conduct of the dominant undertaking tends to restrict competition or, in other words, that the conduct is capable of having that effect. ${ }^{27}$ For example, in Michelin II, the abusive conduct was loyalty-enhancing rebates granted by the manufacturer Michelin to its retailers (dealers) who sold the new replacement and retreaded tyres for trucks to consumers. The rebate system was found to have limited dealers' choice of supplier and made access to the market more difficult. ${ }^{28}$ Although there is some discussion of tyre prices to consumers in the Commission's decision, as Michelin argued that these have fallen in the relevant period, this does not seem to have played a central role in the assessment and is not included in the CFl's judgment. ${ }^{29}$ According to the CFI, the Commission did not examine and was not required to examine the specific effects of the abusive practice; it was highly probable that the fall in Michelin's prices would have been greater if it had not implemented the abusive practices in question. $^{30}$

\footnotetext{
${ }^{25}$ Michelin II (n 21) [241]; Case T-228/97 Irish Sugar plc v Commission [1999] ECR II-2969, [170], upheld on appeal in Case C-497/99 P Irish Sugar plc v EC Commission [2001] ECR I-5333.

${ }^{26}$ Michelin II (n 21) [241]. See also Case T-340/03 France Télécom SA (formerly Wanadoo Interactive SA) v EC Commission [2007] 4 CMLR 21, [195].

${ }_{27}$ Michelin II (n 21) [239]. Similarly British Airways (CFI) (n 21) [293].

${ }^{28}$ Michelin II (n 21) [110].

${ }^{29}$ Michelin Commission Decision (Case COMP/E-2/36.041/PO) 2002/405/EC [2002] OJ L143/1, [337] et seq. Interestingly, the Commission itself recognises the intensity of competition and thus low margins in the sector, ibid [218].

${ }^{30}$ Michelin II (n 21) [258]-[259].
} 
It is not easy to interpret the statements of the CFI in Michelin II and Irish Sugar since finding conduct abusive when it is capable of having an anticompetitive effect is very different from finding conduct abusive merely on the basis of alleged anticompetitive object. Unlike Article 81EC, the provision of Article 82EC itself does not sanction anticompetitive object. This is in conformity with the nature of the provision; a dominant undertaking can only abuse its position if it uses its power abusively and it is not easy to contemplate how the undertaking can abusively use its power with merely having the object to do so without actually using its power. This is particularly true and important for 'exploitative' abuses as further elaborated on below. ${ }^{31}$ Oddly enough, the CFI itself also stated that unlike Article 81(1)EC, Article 82EC contains no reference to the anticompetitive object or anticompetitive effect of the practice referred to, but in the light of the context of Article 82EC, conduct will be regarded as abusive only if it restricts competition. ${ }^{32}$ Indeed, as in the example of predatory pricing, even if the undertaking has the object to predate, a failed attempt at predation would benefit consumers by reduced prices and thus, the effect would not be anticompetitive under a 'consumer welfare' standard.

This, however, does not seem to be the understanding of the Courts. The Courts have held on various occasions that when an undertaking actually implements practices with the aim of restricting competition, the fact that the result sought is not achieved is not enough to avoid the application of Article 82EC. ${ }^{33}$ It has been suggested in the literature that certain decisions of EC Courts and wording in EC Commission guidelines suggest that an 'object or effect' test applies under Article 82EC as well; there is a latent premise that certain kinds of behaviour are to be presumed abusive, such that the burden then shifts to the defendant to establish exceptional circumstances or objective justification. ${ }^{34}$ Moreover, not only object, but also the intent of the

\footnotetext{
${ }^{31}$ See text around $\mathrm{n} 97$.

${ }^{32}$ Michelin II (n 21) [237]. Repeated in Microsoft (n 2) [867].

${ }^{33}$ Irish Sugar (CFI) (n 25) [191]; Michelin II (n 21) [245]; British Airways (CFI) (n 21) [297]; Wanadoo (n 26) [196].

${ }^{34}$ D Sinclair 'Abuse of Dominance at a Crossroads - Potential Effect, Object and Appreciability under Article 82 EC' (2004) 25 (8) European Competition Law Review 491, 497-498. In the context of Article $81 \mathrm{EC}$, Odudu suggests that the justifications for object without effect being sufficient for liability under Article $81 \mathrm{EC}$ are that first, Article $81 \mathrm{EC}$ is not only concerned with seeking out those who have caused
} 
dominant undertaking appears to play a role in determining whether conduct is abusive. ${ }^{35}$ Yet, as Article $82 \mathrm{EC}$ is mainly concerned with unilateral practices being imposed by the dominant undertaking on its trading partners - unlike Article 81EC which tackles multilateral conduct - finding conduct abusive on the basis of mere object in Article 82EC cases raises the question of how one can determine the object of a unilateral practice without effects that can be observed.

Moving from practice to rhetoric, during the EC Commission DG Competition's ongoing review of Article $82 \mathrm{EC}$, it has been repeatedly stated that enforcement of this provision should focus on conduct that has actual or likely restrictive effects on the market and so harms consumers. ${ }^{36}$ The two main reasons for making this the priority are the necessity of enforcement agencies to be cautious about intervening in markets unless there is clear evidence that markets are not working well and the fact that enforcement agencies do not have unlimited resources which require them to focus their efforts on what makes a real difference. The objective of Article $82 \mathrm{EC}$ has thus been expressed as protecting competition on the market, not for its own sake, but rather as a means of enhancing 'consumer welfare' and ensuring the efficient allocation of resources. ${ }^{37}$

Nonetheless, a closer look reveals that a genuine shift to an effects-based approach may not exist, for example, as demonstrated by the definition of 'abuse' in the Discussion Paper adopting that of the ECJ in Hoffmann-La Roche which does not look for harm to consumers. ${ }^{38}$ Indeed, the Director

\footnotetext{
restrictive effects, but with preventing restrictive effects from occurring and second, failure to restrict competition after attempting to do so is a function of chance rather than choice and the choice is sufficient in itself; O Odudu 'Interpreting Article 81(1): Object as Subjective Intention' (2001) 26 (1) European Law Review 60, 71.

${ }^{35}$ Sinclair (n 34) 498-499. For example, the test of predatory pricing in $A K Z O$ includes an intention based assessment; Case C-62/86 AKZO Chemie BV v EC Commission [1991] ECR I-3359, [70] et seq. See also Tetra Pak II (ECJ) (n 20) [41]. For the argument that the 'object' requirement in Article 81EC can be satisfied by the subjective intention of the parties to the restrictive practice see Odudu ( $n$ 34) 60, 70. Cf R Whish Competition Law ( $5^{\text {th }}$ ed Butterworths London 2003) 110 arguing that 'object' means not the subjective intention of the parties, but the objective meaning and purpose of the agreement considered in the economic context in which it is to be applied.

${ }^{36}$ See eg N Kroes, European Commissioner for Competition Policy, 'Preliminary Thoughts on Policy Review of Article 82' Speech at the Fordham Corporate Law Institute New York 23 September 2005, 2; Kroes (n 18) 5; Discussion Paper (n 3) [4].

${ }^{37}$ Kroes (n 36) 3; Kroes (n 18) 5.

38 See in general Akman (n 4) and in particular 822-823.
} 
General of DG Competition has also commented that beyond the question of principle how 'consumer welfare' should be defined in a given case, there might also be operational difficulties in applying a more effects-based approach under Article 82EC. ${ }^{39}$ Since the dominant undertaking has better access to the relevant information than a complainant or the EC Commission, it is challenging to gauge in a specific case the consequences, efficiencies or others, of a challenged practice. Thus, it is suggested that as possible elements of a plausible economic theory of harm, one use proxies and presumptions when applying Article 82EC to make enforcement more practical and swift. Arguably, a pure effects-based approach can be too costly in terms of enforcement. ${ }^{40}$ This is not understandable since the EC Commission itself is promoting an effects-based approach and as mentioned above ${ }^{41}$ one reason for this is, as expressed by the Commissioner, the necessity to focus the efforts of enforcement agencies on what makes a real difference as they do not have unlimited resources. As such, it demonstrates that the EC Commission may be advocating modernisation whose crucial terms, such as the meaning of 'consumer welfare' and how this is to be assessed in individual cases, it has not yet defined.

All in all, it is not possible to give a clear answer to the question of whether anticompetitive effects are necessary for conduct to be abusive under Article 82EC based on the decisional practice and policy declarations studied thus

\footnotetext{
${ }^{39}$ P Lowe, Director General, EC Commission Directorate-General for Competition, 'Consumer Welfare and Efficiency - New Guiding Principles of Competition Policy?' $13^{\text {th }}$ International Conference on Competition and $14^{\text {th }}$ European Competition Day, Munich 27 March 2007, 8. It has also been argued in the literature that a pure effects-based approach cannot be accommodated under the current legislative framework since one must not ignore the rationale that made adoption of Article 82EC necessary: a dominant firm has a 'special responsibility' not to abuse its position precisely because its unilateral behaviour bears an inherent risk for the market structure, competitors, customers and ultimately consumers, since its impact and incidence determines the rules of the game; $V$ Mertikopoulou 'DG Competition's Discussion Paper on the Application of Article 82 of the EC Treaty to Exclusionary Abuses: The Proposed Economic Reform from a Legal Point of View' (2007) 28 (4) European Competition Law Review 241, 250. It is not clear how the author understands the rationale that made the adoption of Article 82EC necessary since the 'special responsibility' of dominant undertakings is not found in Article 82EC and the prohibition of 'abuse' in the provision rather than the dominant position itself shows that the drafters accepted the 'inherent risk' resulting from the existence of such positions. See in general Akman (n 6) and in particular text around n 99 on the intent of the drafters. For the argument that consumers are best served by a competition policy toward exclusionary conduct featuring both form-based and effects-based elements see GJ Werden 'Competition Policy on Exclusionary Conduct: Toward an Effects-Based Analysis?' (2006) 2 (Special Issue) European Competition Journal $53,53$.

40 Lowe (n 39) 8.

${ }^{41}$ See text around 36.
} 
far. The answer appears to be 'yes' in some cases and 'no' in others with no obvious explanation of when and why.

\section{The Subject of Abusive Conduct and the Substance of 'Consumer Welfare'}

As for the second-limb of the question, namely on whom or what the abusive conduct must be observed for finding breach of Article 82EC, it is again not easy to discern an unequivocal understanding. According to the Discussion Paper, the test for the prohibition of 'exclusionary' abuses in Article 82EC is suggested to be one that looks for both actual/likely anticompetitive effects in the market and direct/indirect consumer harm. ${ }^{42}$ It must be noted that the test requires anticompetitive effects in the market and possible harm to consumers. In other words, they are not seen as one and the same thing. ${ }^{43}$ Moreover, although the avoidance of harm to consumers is seen as the ultimate concern of the provision, ${ }^{44}$ the test proposed in the Discussion Paper does not seek proof of any actual or possible harm to consumers. Nowhere is it explained how an assessment of the effects on consumers is to be made. ${ }^{45}$ Thus, apart from the lip service paid to the adoption of an approach which is based on the likely effects on the market, ${ }^{46}$ the stance of DG Competition seems to be almost an implicit assumption that exclusionary behaviour of a dominant undertaking necessarily harms consumers and that the contrary can be proved by the undertaking as a defence. ${ }^{47}$

In any case, even if the EC Commission is moving towards a 'consumer welfare' standard for its application of Article 82EC, it must be noted that it has a peculiar understanding of 'consumer welfare' apart from its problematic understanding of 'consumer' as 'customer'. ${ }^{48}$ The objective of Article 82EC expressed as the protection of competition on the market as a means of 'enhancing consumer welfare and of ensuring an efficient allocation of

\footnotetext{
${ }^{42}$ Discussion Paper (n 3) [55].

43 Unlike, for example, the EAGCP Report which perceives 'competitive harm' as 'harm to consumers'; EAGCP Report (n 18) 7-9.

${ }^{44}$ Discussion Paper (n 3) [4], [54]-[55], [88].

${ }^{45}$ Akman (n 4) 823.

${ }^{46}$ Discussion Paper (n 3) [4].

47 Akman (n 4) 824.

${ }^{48}$ On the problems understanding 'consumer' as 'customer' can cause see Akman (n 5).
} 
resources' 49 clearly demonstrates that consumer welfare and efficient allocation of resources are not seen as one and the same thing. Thus, the 'consumer welfare' concept of the EC Commission obviously does not refer to allocative inefficiency, namely the deadweight loss or the so-called 'triangle'. From an economic understanding of welfare, this leaves only the 'rectangle', namely the transfer of wealth from consumers to producers. ${ }^{50}$ Hence, the 'consumer welfare' concept of the EC Commission appears to refer to the 'wealth transfer' from the customers to the dominant undertaking. The Guidelines on Article 81(3)EC provide further proof of this interpretation:

[r]estrictions by object such as price fixing and market sharing reduce output and raise prices, leading to a misallocation of resources, because goods and services demanded by customers are not produced. They also lead to a reduction in consumer welfare, because consumers have to pay higher prices for the goods and services in question. ${ }^{51}$

Hence, misallocation of resources - allocative inefficiency - is treated separately from 'consumer welfare', perceived as the 'transfer of wealth'. This understanding of 'consumer welfare' of the EC Commission is odd given that elsewhere it has expressly stated its wish not to pursue 'unfair pricing' cases which are logically the cases it should first and foremost pursue with this perception of 'consumer welfare'. ${ }^{52}$ Thus, if the subjects on whom abusive conduct has to be demonstrated are consumers and enhancing 'consumer welfare' means preventing the transfer of wealth from consumers to producers, not only would this imply that there is ultimately one type of abuse

\footnotetext{
${ }^{49}$ Discussion Paper (n 3) [4], [54], [88]. See also Guidelines on Article 81(3)EC (n 5) [13] stipulating the same objective for Article 81EC.

${ }^{50}$ In the case of 'monopoly' the reduction in output and increase in price compared to that under perfect competition leads to a 'deadweight loss' which is the cost to society of a market not operating efficiently; $\mathrm{S}$ Bishop and $\mathrm{M}$ Walker The Economics of EC Competition Law: Concepts, Application and Measurement (2nd ed Sweet\&Maxwell London 2002) 22. Moreover, the increase in price due to the monopoly leads to a 'wealth transfer' from consumers to the monopolist since those who are able to make a purchase pay a higher price compared to that under perfect competition.

${ }^{51}$ Guidelines on Article 81(3)EC (n 5) [21] and similarly [46].

52 See European Commission XXIVth Annual Report on Competition Policy (1994) [207]. Moreover, it is also contradictory with the test for 'predatory pricing' elaborated on in the Discussion Paper. This is because according to the Discussion Paper, it is not necessary to provide proof of recoupment in order to find predation abusive; Discussion Paper (n 3) [122]. However, it is under the 'total welfare' standard that pricing below marginal cost would be condemned without more because it is 'inefficient' regardless of the possibilities of recoupment. Thus, the 'consumer welfare' standard as advocated by the EC Commission would have required it to adopt a recoupment requirement for a finding of abusive predatory pricing. Without recoupment, predatory pricing lowers prices in the market and as a result, 'consumer welfare' is enhanced. This is also the explanation of the US Supreme Court's recoupment requirement, Brooke Group Ltd v Brown and Williamson Tobacco Corp 509 US 209, 224 (1993).
} 
- namely, 'exploitative' - but it would also require serious scrutiny of prices on the market. Whether or not the latter is desirable is very questionable..$^{53}$

All in all, it will be the EC Courts - ultimately the ECJ - that will have the last say on the standard of harm under Article 82EC; the EC Commission's claimed modernisation of application will not succeed unless the Courts endorse its practice. Unfortunately, it is not at all clear from the case law so far whether the Courts have any unified standard while applying Article 82EC and it is especially doubtful whether they will adopt a properly defined 'consumer welfare' standard or require consumer harm to be demonstrated for a finding of abuse.

For example, the CFI held in Van den Bergh that Article 82EC prohibits a dominant undertaking from eliminating a competitor and from strengthening its position by recourse to means other than those based on 'competition on the merits'. ${ }^{54}$ Further, it went on to find that '[t]he prohibition laid down in that provision is also justified by the concern not to cause harm to consumers'. Thus, from the Court's expression, it is obvious that the concern not to cause harm to consumers is not the ultimate justification of Article 82EC, but it is also a legitimate concern.

In an order suspending the EC Commission decision adopting interim measures in the IMS Health case, the CFI expressed the primary purpose of Article 82EC as that of preventing distortion of competition and especially of safeguarding the interests of consumers, rather than to protect the position of particular competitors and criticised the EC Commission for ignoring this purpose by equating the interests of competitors with the interests of competition. ${ }^{55}$ Strikingly, the President of the ECJ held in the appeal of that order that this reasoning of the CFI could not be accepted without reservation, in so far as it could be understood as excluding protection of the interests of

\footnotetext{
${ }^{53}$ On why the abuse of 'unfair pricing' is problematic see P Akman 'To Abuse, or not to Abuse: Unfair Pricing under Article 82EC' on file with the author.

${ }^{54}$ Van den Bergh (CFI) (n 20) [157].

${ }^{55}$ Order of the President of the Court of First Instance of 26 October 2001 in Case T-184/01 R IMS Health v EC Commission [2001] ECR II-3103, [145].
} 
competing undertakings from the aim pursued by Article 82EC, even though such interests cannot be separated from the maintenance of an effective competition structure. ${ }^{56}$ It has been commented that by perspicuously contradicting precisely the passage in which the CFI saw the main purpose of Article 82EC as lying in safeguarding the 'interests of consumers', the President of the ECJ has thus interpreted Article 82EC at the same time in terms of the 'traditional' concept of the 'protection of competition'. ${ }^{5}$ More important is perhaps that the President deemed the interests of competing undertakings as inseparable from the maintenance of 'effective competition'. Although protecting the interests of competing undertakings may at times coincide with enhancing consumer welfare, it is exactly when this does not occur that the controversy of 'protecting competitors' as opposed to 'protecting competition' becomes an issue. Yet, this does not appear to have raised any concern for the President of the ECJ in this instance.

In the same vein, Advocate General Kokott argued in British Airways that Article 82EC, like the other competition rules of the Treaty, is not designed only or primarily to protect the immediate interests of individual competitors or consumers, but to protect the structure of the market and thus competition as such (as an institution) which has already been weakened by the presence of the dominant undertaking in the market. ${ }^{58}$ In this way, consumers are also indirectly protected. The conduct of a dominant undertaking is not, therefore, to be regarded as abusive within the meaning of Article 82EC only once it has concrete effects on individual market participants, be they competitors or consumers. ${ }^{59}$ The Advocate General held that it was sufficient to demonstrate that the conduct of a dominant undertaking is likely to make it difficult or impossible for its competitors to gain access to the market and its business partners to choose between various sources of supply or business partners, unless there is an objective justification for it. ${ }^{60}$ Where there is such a

\footnotetext{
${ }^{56}$ Order of the President of the Court of Justice of 11 April 2002 in Case C-481/01 NDC Health GmbH \& Co KG and NDC Health Corporation v EC Commission and IMS Health Inc [2002] ECR I-3401, [84].

${ }^{57} \mathrm{M}$ Dreher and M Adam 'Abuse of Dominance under Reform - Sound Economics and Established Case Law' (2007) 28 (4) European Competition Law Review 278, 280.

${ }^{58}$ Opinion of Advocate General Kokott on 23 February 2006 in Case C-95/04 British Airways plc v EC Commission [2007] ECR I-2331, [68].

${ }^{59}$ Opinion of Advocate General Kokott in British Airways (n 58) [69].

${ }^{60}$ Opinion of Advocate General Kokott in British Airways (n 58) [87].
} 
hindrance to remaining competition, it can be assumed that, indirectly, consumers are also disadvantaged. Thus, in the Advocate General's statement one can observe the line of thought proceeding from likely harm to competitors (by making access difficult or impossible) to likely harm to competition to likely harm to consumers. Indeed, the Advocate General expressed that for a finding of 'prejudice to consumers' under Article 82(b)EC, it would be sufficient to prove that, without objective justification, the conduct of the dominant undertaking (in this case rebates and bonuses) makes it difficult or impossible for its competitors to compete with it. ${ }^{61}$ As such, it is clear that likely harm to consumers is presumed to follow likely harm to competition which is presumed to result from likely harm to competitors.

The ECJ in the appeal of British Airways, repeated its holding in Continental Can that Article 82EC is aimed not only at practices which may cause prejudice to consumers directly, but also at those which are detrimental to them through their impact on an effective competition structure, such as is mentioned in Article 3(1)(g)EC. ${ }^{62}$ Similarly in France Télékom against the argument of Wanadoo that consumers were not harmed by its pricing but on the contrary, benefited from it, the CFI repeated the same holding of the ECJ in Continental Can; thus, lack of consumer harm was not deemed relevant. ${ }^{63}$

Likewise, according to the EC Commission, Article 82EC does not require it to be demonstrated that the conduct in question had any actual or direct effect on consumers: competition law concentrates upon protecting the market structure from artificial distortions because by doing so the interests of the consumer in the medium to long term are best protected. ${ }^{64} \mathrm{~A}$ line of conduct of a dominant undertaking is abusive as soon as it runs counter to the purpose of protecting competition in the internal market from distortions as

\footnotetext{
${ }^{61}$ Opinion of Advocate General Kokott in British Airways ( $\mathrm{n}$ 58) [89]. In the appeal, the ECJ held that in determining whether the discounts or bonuses constitute abuse, it first has to be determined whether they can produce an exclusionary effect, that is to say whether they are capable, first, of making market entry very difficult or impossible for competitors of the undertaking in a dominant position and secondly, of making it more difficult or impossible for its co-contractors to choose between various sources of supply or commercial partners; British Airways (ECJ) (n 21) [68].

62 British Airways (ECJ) (n 21) [106].

63 Wanadoo (n 26) [266].

${ }^{64}$ British Airways (CFI) (n 21) [264].
} 
stipulated in Article 3(1)(g)EC. Therefore, what is to be proved is the mere likelihood of the conduct in question hindering the maintenance or development of competition still existing in the market by means other than competition on the merits, thereby prejudicing the goal of effective and undistorted competition in the Common Market. ${ }^{65}$

A similar line of thought can be observed in the recent Microsoft decision of the CFI. ${ }^{66}$ In that case, while assessing whether Microsoft's refusal to supply information to its competitors that was necessary for their work group server operating systems to achieve interoperability with Microsoft's (Windows) work group server operating system, the CFI held that

[s]hould it be established ... that the existing degree of interoperability does not enable developers of non-Microsoft work group server operating systems to remain viably on the market for those operating systems, it follows that the maintenance of effective competition on that market is being hindered. ${ }^{67}$

The CFI found that this was indeed the case and Microsoft's refusal to supply the necessary interoperability information was an abuse of its dominant position. ${ }^{68}$ Moreover, the CFI clarified that 'likely to eliminate competition' and 'risk of elimination of competition' are concepts used without distinction by the EC judicature to convey the same idea, namely that Article 82EC does not apply only from the time when there is no more or practically no more competition on the market. ${ }^{69}$ This is because if the EC Commission were required to wait until competitors were eliminated from the market or until their elimination was sufficiently imminent, before being able to take action under Article $82 \mathrm{EC}$, that would clearly run counter to the objective of that provision. ${ }^{70}$ That objective is 'to maintain undistorted competition on the common market and, in particular, to safeguard that competition that still exists on the relevant market'. ${ }^{71}$ Hence, it is not necessary to demonstrate that all competition on the market would be eliminated since what matters is

\footnotetext{
${ }^{65}$ Opinion of Advocate General Kokott in British Airways (n 58) [71]. The Advocate General found that the distinction between 'capable of having' and 'likely to have' is purely semantic, ibid [76].

${ }_{66}$ Microsoft (n 2).

${ }^{67}$ Microsoft (n 2) [229].

${ }^{68}$ Microsoft (n 2) [421], [620], [712].

${ }^{69}$ Microsoft (n 2) [561].

${ }^{70}$ Microsoft (n 2) [561].

${ }^{71}$ Microsoft (n 2) [561].
} 
that the conduct in question is liable to or is likely to eliminate all effective competition on the market. ${ }^{72}$ Moreover, the fact that the competitors of the dominant undertaking retain a marginal presence in certain niches on the market cannot suffice to substantiate the existence of such competition. ${ }^{73}$ It is striking that the CFI has not referred to the interests of consumers while expressing the objective of Article 82EC. It has rather linked the survival of the existing competitors with the maintenance of effective competition.

Although these findings of the CFI suggest that the Court's understanding of 'effective competition' is closely related to how many competitors there are on the market, the Court did consider the interests of customers and consumers as well. As such, it found that the absence of interoperability had the effect of reinforcing Microsoft's competitive position particularly because it induced consumers to use its work group operating system in preference to its competitors', although its competitors' programmes offered features to which consumers attached great importance. ${ }^{74}$ Thus, the limitation placed on 'consumer choice' by Microsoft's conduct was a factor in finding abuse. ${ }^{75}$

Unlike Article 82EC, the picture under Article 81EC appears somewhat different and some of the references to objectives under the latter are broad enough to express objectives of the former as well. ${ }^{76}$ One of the rare and recent instances of the Courts' referring directly to the 'well-being' of consumers, namely end-users in the context of EC competition rules is found in the Österreichische Postsparkasse AG decision of the CFI where the Court found that the ultimate purpose of the rules that seek to ensure that competition is not distorted in the internal market is to increase the well-being of consumers'. ${ }^{77}$ The CFI repeated the same argument in another Article 81EC decision, namely GlaxoSmithKline by expressing that as the objective of

\footnotetext{
${ }_{73}^{72}$ Microsoft (n 2) [563].

${ }^{73}$ Microsoft (n 2) [563].

${ }_{75}^{74}$ Microsoft (n 2) [422].

${ }^{75}$ Microsoft (n 2) [652]. On the relation between 'choice' and 'consumer welfare' see L Lovdahl Gormsen 'Can the Consumer Welfare Standard Handle the Concept of Choice?' on file with the author.

${ }^{76}$ In any case, according to the ECJ Articles 81 and 82EC seek to achieve the same aim; Case 6/72 Europemballage Corp and Continental Can Co Inc v Commission [1973] ECR 215 [11], [25].

77 Joined Cases T-231/01 and T-214/01 Österreichische Postsparkasse AG and Bank für Arbeit und Wirtschaft AG v EC Commission [2006] ECR II-1601, [115]. The term used is 'well-being' ('Wohlergehen') and not 'welfare' ('Wohlfahrt') in the original German text as well.
} 
the Community competition rules is to prevent undertakings, by restricting competition between themselves or with third parties, from reducing the 'welfare of the final consumer' of the products in question, it is necessary to demonstrate that the limitation in question restricts competition, 'to the detriment of the final consumer'. ${ }^{78}$ Furthermore, the CFI held that as regards the examination under Article 81(3)EC, the EC Commission has a margin of discretion subject to a restricted judicial review, in weighing up the advantages expected from the implementation of the agreement and the disadvantages which the agreement entails for the 'final consumer' owing to its impact on competition. $^{79}$

Another direct reference to 'consumer welfare' can be found in the Opinion of Advocate General Jacobs in Syfait where he argued that one possible consequence of prohibiting any restriction of supply by dominant pharmaceutical undertakings intended to limit parallel trade would be an incentive for such undertakings not to market their products in Member States where prices are fixed at a low level. ${ }^{80}$ However, since the legal and moral obligations upon undertakings might render it difficult for them to withdraw products already marketed in those States, more credibly, they might delay the launch of new products in those States. Hence, the levels of output and 'consumer welfare' generated by some pharmaceutical products would fall within the Community. ${ }^{81}$ Similarly, the regulatory negotiation of prices in lowprice Member States would almost certainly become difficult; there would be considerable pressure for prices to rise in those States if they were to be generalised, by process of parallel trade, across the Community. Such price

\footnotetext{
${ }^{78}$ GlaxoSmithKline (n 2) [171]. See also ibid [118]-[119]. The CFI held that parallel trade is to be protected not as such, but in so far as it favours the development of trade, on the one hand, and the strengthening of competition, on the other hand, that is to say, in this second respect, in so far as it gives final consumers the advantages of effective competition in terms of supply or price; ibid [121]. Consequently, while it is accepted that an agreement intended to limit parallel trade must in principle be considered to have as its object the restriction of competition, that applies in so far as the agreement may be presumed to deprive final consumers of those advantages, ibid. The Court found that this presumption could not be made in this case, ibid [134].

${ }^{79}$ GlaxoSmithKline (n 2) [244].

80 Opinion of Advocate General Jacobs in Syfait (n 2) [90]-[91].

${ }^{81}$ Opinion of Advocate General Jacobs in Syfait (n 2) [91].
} 
rises would again reduce output and 'consumer welfare' in the States where they occurred. ${ }^{82}$

Impact of conduct on consumers have been regarded in some other findings of abuse as well, such as the Italian railways case where the dominant national railway carrier in Italy (FS) refused to provide traction, an activity which it routinely performs, to a German railway undertaking (GVG). This was found not to be justified by any objective reason and to protect FS's monopoly position in the downstream market for international passenger rail services between Basle and Milan, namely the route on which GVG wanted to offer service. ${ }^{83}$ It therefore constituted an abuse of a dominant position; FS's refusal to provide traction to GVG was found to eliminate a potential competitor and thereby hinder the growth of competition in the downstream market. This harmed consumers who would have benefited from alternatives to existing rail passenger services.

In the same vein, Advocate General Jacobs stated in Oscar Bronner that the primary purpose of Article 82EC is to prevent distortion of competition - and in particular to safeguard the interests of consumers - rather than to protect the position of particular competitors. ${ }^{84}$ It may therefore, for example, be unsatisfactory, in a case in which a competitor demands access to a raw material in order to be able to compete with the dominant undertaking on a downstream market in a final product, to focus solely on the latter's market power on the upstream market and conclude that its conduct in reserving to itself the downstream market is automatically an abuse. Such conduct would not have an adverse impact on consumers unless the dominant undertaking's final product is sufficiently insulated from competition to give it market power.

\footnotetext{
82 Opinion of Advocate General Jacobs in Syfait (n 2) [92]. The Advocate General states that the conclusion he reaches, i.e. that a restriction of supply by a dominant undertaking to limit parallel trade is not necessarily abusive, is highly specific to the pharmaceutical industry in its current condition and to the particular type of conduct at issue in the proceedings; ibid [100]-[101]. According to him, it is highly unlikely that any other sector would exhibit the characteristics which have led to this conclusion; ibid [102].

83 Georg/Ferrovie (GVG/FS) Commission Decision (Case COMP 37.685) 27.08.2003 (unreported) [145]. FS provided rail passenger transport service from Basle to Milan in cooperation with a Swiss undertaking; ibid [10].

${ }_{84}$ Opinion of Advocate General Jacobs in Case C-7/97 Oscar Bronner GmbH \& Co KG v Mediaprint Zeitungs- und Zeitschriftenverlag GmbH \& Co KG [1998] ECR I-7791, [58].
} 
Similarly, Advocate General Warner had argued in Commercial Solvents that '[t]he consumer, after all, is interested only in the end product, and it is detriment to the consumer, whether direct o[r] indirect, with which Article $8[2 E C]$ is concerned'. 85

All in all, there is no clear answer to the question of on whom/what the abusive conduct must be demonstrated for a finding of breach of Article 82EC: in some cases, it has been held to be competition, in some cases competitors and in others consumers. As such, the current situation of the law regarding the standard of harm under Article 82EC remains vague without any clear rules.

\section{Reconciliation between Practice and Rhetoric}

The only thing that seems clear enough in the area of the standard of harm under Article 82EC is the dissonance between practice and rhetoric. Although 'consumer welfare' is declared to be the ultimate goal of EC competition rules, the decisional practice does not convincingly support this. Not only does there appear to be a lack of consensus between the EC Commission and Courts, there also seems to be a lack of coherence within the application of Article 82EC by the EC Commission, especially when one compares it with its policy declarations. Further, there appears to be a lack of coherence between the case law of the EC Courts on Article 81EC and 82EC; cases like Österreichische Postsparkasse AG and GlaxoSmithKline come much closer to embracing a 'consumer welfare' standard than any Article 82EC decision has ever done.

It has been commented that competition enforcement as distinct from policy may not always bring a direct benefit to consumers and may not always lead to an increase in choice or reduction in price. ${ }^{86}$ Competition enforcement often merely relies on vague statements about the consumer impact that may

\footnotetext{
${ }^{85}$ Opinion of Advocate General Warner in Cases 6 and 7/73 Istituto Chemioterapico Italiano Spa and Commercial Solvents Corp v Commission [1974] ECR 223, 266.

${ }^{86}$ I Haracoglou 'Competition Policy Law, Consumer Policy and the Retail Sector: the systems' relation and the effects of a strengthened consumer protection policy on competition law' (2007) 3 (2) The Competition Law Review 175, 181.
} 
ignore the effect on the ultimate consumer, let alone exhaustively address the 'consumer interest'. ${ }^{87}$ It has rightly been argued that to establish a competition law violation, there is no requirement to prove that consumers have been harmed and consumer harm itself may be insufficient to trigger a finding of competition violation. ${ }^{88}$ As the law stands, competition law violations rest on a test of 'harm to competition' rather than 'harm to consumers'. ${ }^{89}$ While the EC Commission may at times refer more explicitly to the consumer as the ultimate benefactor, the consideration of the consumer interest is often merely vague, in terms of considering it to be a natural consequence of 'harm to competition', rather than as a direct 'harm to consumers'. ${ }^{90}$

The decisional practice studied above is largely consistent with this view: although there are references to 'consumer welfare' and 'harm to consumers', it is not clear whether these references are merely catchphrases inserted by default in decisions or whether they actually affect the decision reached. Moreover, there is not a consistent line of argument in practice; some decisions explicitly reject the necessity of considering effects on and harm to consumers, while some of them require such an assessment.

It has been suggested that although harm to an 'effective competitive structure' has sometimes been mentioned as a possible alternative to direct consumer harm, the two concepts should amount to the same thing: unless there is consumer harm, there is no relevant harm to the structure of competition'. ${ }^{91}$ Thus, there can be no case for intervention under competition law where there is harm to the competitive process, but none to consumers. ${ }^{92}$ As argued in the EAGCP Report commissioned by DG Competition, the standard for assessing whether a given practice is detrimental to 'competition' or whether it is a legitimate tool of 'competition' should be derived from the effects of the practice on consumers. ${ }^{93}$ Ignoring such effects in favour of a

\footnotetext{
${ }^{87}$ Haracoglou (n 86) 181.

${ }^{88}$ Haracoglou (n 86) 180.

${ }^{89}$ Haracoglou (n 86) 180.

90 Haracoglou (n 86) 199.

${ }^{91}$ O'Donoghue and Padilla (n 19) 221; J Vickers 'Abuse of Market Power' (2005) 115 The Economic Journal F244, F259.

92 O'Donoghue and Padilla (n 19) 221-222.

${ }^{93}$ EAGCP Report (n 18) 8.
} 
legal presumption of effect as advocated in Michelin // is plainly inconsistent with the EC Commission's current emphasis on an economics-based approach and the entire basis for the ongoing review of policy under Article 82EC. ${ }^{94}$ In contrast to merger control, abuse of dominance cases involve only situations in which the defendant is already in a dominant position and thus, usually concern known present facts and established conduct in which case it should normally be possible to consider whether the market is more consistent with potential exclusion or a competitive environment. ${ }^{95}$ In most cases, there should be relevant information regarding actual effects or information on which reasonable assumptions as to future effects can be made. ${ }^{96}$

The argument that one should look for evidence of effects of conduct is especially true and important in 'exploitative' abuse allegations - exploitation must be observable; one cannot exploit without actually exploiting. Although exclusion may be likely to occur in the future even if it is not happening at the moment, to base a case on 'exploitation' one must be able to show that there is exploitation. Finding abuse in the mere likelihood of exploitation - if one transposed the decisional practice on exclusionary abuses - would not be consistent with Article 82EC: the fact that a dominant position itself is not prohibited demonstrates that it is not the likelihood of exploitation that is abusive since that likelihood always exists as long as there is a dominant position. Conduct becomes abusive only when the dominant undertaking actually uses its power to 'exploit', not when it is likely to exploit. The presumption underlying Article 82EC as proven by the lack of prohibition of dominance itself is that dominant undertakings may not always use their power to exploit. ${ }^{97}$ Thus, unless expected as a result of exclusionary conduct, mere exploitation should be demonstrable to be abusive.

Overall, it is questionable whether mere likelihood of anticompetitive harm should be sufficient for a finding of 'exclusionary' abuse when one recognises

\footnotetext{
${ }^{94}$ O'Donoghue and Padilla (n 19) 219. Michelin II (n 21).

${ }^{95}$ O'Donoghue and Padilla (n 19) 220.

${ }^{96}$ O'Donoghue and Padilla (n 19) 220.

97 Joliet (n 6) 131.
} 
that 'abuse' requires the use of power and as such, Article $82 \mathrm{EC}$ is a tool of ex post intervention, unlike merger control. ${ }^{98}$ When the likelihood of anticompetitive harm is deemed sufficient, then it remains to be answered when effects are to be deemed so likely that intervention is justified. So far, it remains unknown what the required probability is for likely effects to warrant intervention.

Another question rightly raised is that of what happens in cases where damage to consumers is direct and there is no (direct) effect on the structure of competition. ${ }^{99}$ This is again especially relevant for 'exploitative' abuses. Haracaoglou argues that although untested, it appears that the ambit of Article 82EC is sufficiently wide to allow for an interpretation that would cover the situation where access to a product or service is restricted despite consumer demand and there is no apparent harm to competition; such a practice could be deemed to 'limit production, markets or technical development to the prejudice of consumers'. ${ }^{100}$

However, it must be remembered that Article 82EC is not a provision of consumer law, but a provision of competition law. As also held by the EC Courts, although Article 82EC contains no reference to the anticompetitive object or anticompetitive effect of the practice referred to, in the light of the context of Article $82 \mathrm{EC}$, conduct will be regarded as abusive only if it restricts competition. ${ }^{101}$ Thus, mere consumer harm should not be sufficient for conduct to be abusive if it is not tied to some effect on competition or due to some conduct affecting competition. Hence, just like mere harm to the structure of competition not being enough for conduct to be abusive, mere consumer harm should not be enough on its own either: if the standard is 'consumer welfare', then harm to consumers resulting from a restriction of competition should be the test for finding conduct abusive under Article 82EC. The 'restriction of competition' should be part of the test even if it may remain

\footnotetext{
${ }^{98}$ Cf L Lovdahl Gormsen 'Article 82 EC: Where are we coming from and where are we going to?' (2005) 2 (2) The Competition Law Review 5, 25 n 109 arguing that Article 82EC is ex ante and ex post.

99 Haracoglou (n 86) 204.

${ }_{100}^{100}$ Haracoglou (n 86) 204.

${ }^{101}$ Michelin II (n 21) [237]; Microsoft (n 2) [867].
} 
vague in certain cases; it is necessary for separating consumer law violations from competition law violations since competition law is not apt or supposed to attack all practices merely because they harm the 'consumer'. There are many practices which may justify sanctioning simply because of the desire to protect the 'consumer' in her status as the 'consumer', such as aggressive commercial practices which do not necessarily have any implications for 'competition'. As such, requiring both harm to competition and harm to consumers to find conduct abusive in Article 82EC cases can help to correct the dissonance between the practice and rhetoric on the standard of harm under Article 82EC substantively.

\section{Conclusion}

The EC Commission has to either say as it does or do as it says. This has not been the case with the application of and policy on Article 82EC so far. Although all policy declarations greatly emphasise the objective of 'consumer welfare', it is not easy to observe this objective in the decisional practice of the EC Commission or Courts. This is because there does not appear to be a unified and coherent test applied by the EC Commission and Courts in finding behaviour of a dominant undertaking abusive. At the moment, it is not even clear whether effects on consumers or the market are relevant or whether merely an anticompetitive object is sufficient. It is also not clear what the relation between the likelihood of anticompetitive effects with the form of conduct is. It is similarly ambiguous what the relevant probability is at which likely effects can be deemed sufficient to justify a finding of abuse.

In particular for exploitative abuses, it must be recognised that mere likelihood of anticompetitive effects cannot suffice for conduct to be abusive since this would not be consistent with the fact that Article 82EC does not prohibit a dominant position itself. Hence, for abusive exploitation to occur, the dominant undertaking has to use its power to exploit. The use of that power should be observable and thus demonstrable in terms of its actual effects since otherwise abuse would not have been proven. This goes for exclusionary abuses as well, once it is accepted that Article 82EC provides an ex post intervention mechanism. Therefore, if the standard of harm is 'consumer 
welfare' then harm to competition resulting in harm to consumers should be the test of abuse.

From the case law studied above, it is questionable whether the EC Courts will modernise their application of Article 82EC as per the call of the EC Commission and whether they will adopt a properly defined 'consumer welfare' standard. It is, however, also doubtful whether the EC Commission itself has a properly defined 'consumer welfare' standard which it in fact follows in its decisional practice. To reconcile its practice with its rhetoric the EC Commission either has to demonstrate in its decisions unambiguously that it follows a well-defined 'consumer welfare' approach or it should unambiguously declare what approach it follows in practice. Currently, Article 82EC remains as an area of law with more questions than answers. 